\title{
The dual role of microbes in corrosion
}

\author{
Nardy Kip and Johannes A van Veen \\ Department of Microbial Ecology, Netherlands Institute of Ecology (NIOO-KNAW), Wageningen, \\ The Netherlands
}

\begin{abstract}
Corrosion is the result of a series of chemical, physical and (micro) biological processes leading to the deterioration of materials such as steel and stone. It is a world-wide problem with great societal and economic consequences. Current corrosion control strategies based on chemically produced products are under increasing pressure of stringent environmental regulations. Furthermore, they are rather inefficient. Therefore, there is an urgent need for environmentally friendly and sustainable corrosion control strategies. The mechanisms of microbially influenced corrosion and microbially influenced corrosion inhibition are not completely understood, because they cannot be linked to a single biochemical reaction or specific microbial species or groups. Corrosion is influenced by the complex processes of different microorganisms performing different electrochemical reactions and secreting proteins and metabolites that can have secondary effects. Information on the identity and role of microbial communities that are related to corrosion and corrosion inhibition in different materials and in different environments is scarce. As some microorganisms are able to both cause and inhibit corrosion, we pay particular interest to their potential role as corrosion-controlling agents. We show interesting interfaces in which scientists from different disciplines such as microbiology, engineering and art conservation can collaborate to find solutions to the problems caused by corrosion.
\end{abstract}

The ISME Journal (2015) 9, 542-551; doi:10.1038/ismej.2014.169; published online 26 September 2014

\section{Introduction}

Corrosion is a global problem that affects a large variety of industries and municipal services, such as shipping, oil refinery, construction, sewage and drinking water systems, and upkeep of historical buildings and statues (Sánchez del Junco et al., 1992; Warscheid and Braams, 2000; Videla and Herrera, 2005).

Corrosion refers to the deterioration of materials, such as iron, steel, concrete and stone (see for other reviews Warscheid and Braams, 2000; Videla and Herrera, 2005, 2009). Biocorrosion is the result of electrochemical reactions that are influenced or driven by microorganisms, which are often present as biofilms. In recent years it has become clear that microbes do not only cause corrosion, but they can also inhibit or protect against corrosion, which is summarized in the terms microbiologically influenced corrosion (MIC) and MIC inhibition (MICI) (Zuo, 2007). This review aims to show the recent progress on MIC and MICI mechanisms and tries to integrate the data from studies on different materials and from different scientific fields to update on the

Correspondence: N Kip, Department of Microbial Ecology, Netherlands Institute of Ecology (NIOO-KNAW), PO Box 50, Wageningen $6708 \mathrm{~PB}$, The Netherlands.

E-mail: n.kip@nioo.knaw.nl

Received 11 June 2014; accepted 11 August 2014; published online 26 September 2014 present state of knowledge and on the identification of promising approaches for corrosion prevention and protection.

\section{Metal corrosion}

Metal corrosion results from (bio) chemical reactions that release either electrons or ions from the metal. Corrosive chemicals, like acids, stimulate anodic reactions. By consuming hydrogen, microbes stimulate cathodic reactions (Videla and Herrera, 2005) and they may also stimulate corrosion through the secretion of enzymes and acidic metabolites (Table 1).

The main types of bacteria associated with the corrosion of iron and steel are sulfate-reducing bacteria (SRB), sulfur-oxidizing bacteria, iron oxidizers, iron reducers, manganese oxidizers and microbes that secrete organic acids and produce extracellular polymeric substances (EPS) (Hamilton, 2003; Zuo, 2007; Table 2). The microbiology and corrosion effect of SRB and iron oxidizers have recently been reviewed (Herrera and Videla, 2009; Emerson et al., 2010; Enning and Garrelfs, 2013). Genomic analysis might provide interesting information on the genetics and regulation of the metabolic processes leading to corrosion, but there are only few genomes available of pure cultures of microbes published related to corrosion and a few molecular studies on corroded materials, which will be discussed in the 'Perspectives' section. 
Most damaging corrosion takes place in the presence of a multispecies biofilm. In such biofilms the interactions between different species may induce a cascade of biochemical reactions in the oxic and anoxic parts of the biofilm and exacerbate corrosion (Zuo, 2007; Videla and Herrera, 2009). Multiple corrosion-causing organisms in a biofilm can act synergistic and contribute to more severe corrosion than when only one single species is present (Zuo, 2007; Lee et al., 2013).

Recently, two different mechanisms of iron corrosion were described, that is, chemical MIC (CMIC) and electrical MIC (EMIC) (Enning et al., 2012; Enning and Garrelfs, 2013; Venzlaff et al., 2013). These two mechanisms differ in the source of electrons used by the SRB, which was shown to be species specific. The electrons originate from a hydrogen film on the metal surface (CMIC) or they can be directly extracted from $\mathrm{Fe}^{\circ}$ (EMIC). In EMIC the produced sulfuric corrosion crust enables the transfer of electrons to the microbes even if they are not in direct contact with the iron. This explains why microorganisms and the crust can continue to grow, which is not the case in CMIC, where corrosion and crust formation stop upon loss of direct metal contact (see Figure 1). Direct electron

Table 1 Examples of corrosion reactions influenced by microbes

\begin{tabular}{lc}
\hline Anodic reaction & $\mathrm{Me} \rightarrow \mathrm{Me}^{2+}+2 \mathrm{e}^{-}$ \\
& $\mathrm{H}_{2} \mathrm{O} \rightarrow \mathrm{H}^{+}+\mathrm{OH}^{-}$ \\
Anodic depolarization by sulfide & $\mathrm{Fe}^{2+}+\mathrm{S}^{2-} \rightarrow \mathrm{FeS}$ \\
Cathodic reaction & $2 \mathrm{H}^{+}+2 \mathrm{e}^{-} \rightarrow \mathrm{H}_{2}$ \\
& $1 / 2 \mathrm{O}_{2}+\mathrm{H}_{2} \mathrm{O}+2 \mathrm{e}^{-} \rightarrow 2 \mathrm{OH}^{-}$ \\
Cathodic depolarization by SRB & $\mathrm{SO}_{4}^{2-}+\mathrm{H}_{2} \rightarrow \mathrm{S}^{2-}+4 \mathrm{H}_{2} \mathrm{O}$
\end{tabular}

Abbreviation: SRB, sulfate-reducing bacteria. uptake is also shown for methanogens, but the produced corrosion crust is not conductive and so corrosion will probably stop once direct metal contact is lost, that is, the methanogenic Archaea are no longer in direct contact with the metal surface (Enning et al., 2012).

\section{Stone and concrete corrosion}

Biofilms on concrete, stone and marble are visible as a colored slimy layer or a dry crust (Warscheid and Braams, 2000). These microbial assemblages can directly cause physical and chemical deterioration of historical buildings and works of art (Gaylarde et al., 2011). Moreover, the slimy (EPS) biofilms retain moisture, which may induce mechanical stress on the structure upon freeze-thaw cycles.

Different groups of microorganisms are involved in stone corrosion. At the stone-air interface, the available light may result in growth of phototrophs such as algae and cyanobacteria (Lamenti et al., 2000). Fungi can bore into the stone and produce extracellular enzymes and metabolites that cause chemical and physical damage (Warscheid and Braams, 2000). Bacteria-producing acids, for example, nitrifying bacteria dissolve calcareous stone, whereas other bacteria and fungi feed on paint or other coatings applied to protect the material (Vollertsen et al., 2008; Mapelli et al., 2012).

Corrosion may also occur at the stone-soil interface, including the foundations of buildings and sewer systems. Sewer systems made of concrete can be severely damaged by microorganisms such as Acidothiobacilli spp., which produce sulfuric acids that react with the calcitic binding material of the concrete (Crispim and Gaylarde, 2005).

Table 2 Examples of microorganisms found related to microbiologically influenced corrosion of metal (reviewed as well in Beech and Gaylarde, 1999)

\begin{tabular}{|c|c|c|c|c|}
\hline Type & & Trait & Effect & References \\
\hline $\begin{array}{l}\text { Sulfide reducers } \\
\text { Desulvovibrio } \mathrm{sp} . \\
\text { Desulfomonas } \mathrm{sp} .\end{array}$ & Anaerobic & $\begin{array}{l}\text { Use } \mathrm{H}_{2} \text { to reduce } \mathrm{SO}_{4}^{2-} \text { to } \mathrm{S}^{2-} \text { : } \\
\text { precipitation of } \mathrm{H}_{2} \mathrm{~S} \text { and } \mathrm{FeS}\end{array}$ & $\begin{array}{l}\text { Cathodic depolarization by hydrogen } \\
\text { uptake, anodic depolarization by } \\
\text { corrosive iron sulfides }\end{array}$ & $\begin{array}{l}\text { Enning et al., 2012; Rao et al., } \\
\text { 2000; Venzlaff et al., 2013; } \\
\text { Wikieł et al., } 2014\end{array}$ \\
\hline $\begin{array}{l}\text { Iron oxidizers/manganese oxidizers } \\
\text { Gallionella sp. } \\
\text { Leptothrix sp. } \\
\text { Mariprofundus sp. }\end{array}$ & Aerobic & $\begin{array}{l}\mathrm{Fe}^{2+} \text { to } \mathrm{Fe}^{3+} \text { and } \mathrm{Mn}^{2+} \text { to } \\
\mathrm{Mn}^{3+} \text { : Iron oxide and manga- } \\
\text { nese dioxide formation }\end{array}$ & $\begin{array}{l}\text { Deposition of cathodically reactive } \\
\text { ferric and manganic oxides }\end{array}$ & $\begin{array}{l}\text { Lee et al., 2013; McBeth et al., } \\
\text { 2011; Rao et al., 2000; } \\
\text { Linhardt, } 2010\end{array}$ \\
\hline $\begin{array}{l}\text { Iron reducers } \\
\text { Pseudomonas sp. } \\
\text { Shewanella sp. } \\
\text { Geothermobacter sp. }\end{array}$ & Aerobic & $\begin{array}{l}\text { Reduce } \mathrm{Fe}^{3+} \text { to } \mathrm{Fe}^{2+} \text {, manga- } \\
\text { nese or iron oxide reduction }\end{array}$ & $\begin{array}{l}\text { Reduction of iron and manganese } \\
\text { oxides }\end{array}$ & $\begin{array}{l}\text { Lee et al., 2013; } \\
\text { Rao et al., } 2000\end{array}$ \\
\hline $\begin{array}{l}\text { Sulfide oxidizers } \\
\text { Thiobacillus sp. }\end{array}$ & Aerobic & $\begin{array}{l}\text { Oxidizes } \mathrm{S}^{2-} \text { and } \mathrm{SO}_{3}^{2-} \text { to } \\
\mathrm{H}_{2} \mathrm{SO}_{4}\end{array}$ & Acids corrode metal & Li et al., 2008 \\
\hline $\begin{array}{l}\text { Acid producing bacteria and fungi } \\
\text { Clostridium sp. } \\
\text { Fusarium sp. } \\
\text { Penicillium sp. } \\
\text { Hormoconis sp. }\end{array}$ & $\begin{array}{l}\text { Aerobic and } \\
\text { anaerobic }\end{array}$ & $\begin{array}{l}\text { Production acids, e.g., nitric } \\
\text { acid, sulfuric acid, and organic } \\
\text { acids }\end{array}$ & $\begin{array}{l}\text { Dissolve iron, chelate copper, zinc } \\
\text { and iron }\end{array}$ & $\begin{array}{l}\text { Juzeliūnas et al., 2007; Little } \\
\text { et al., 2001; Usher et al., } 2014\end{array}$ \\
\hline $\begin{array}{l}\text { Slime forming bacteria } \\
\text { Clostridium sp. } \\
\text { Bacillus sp. } \\
\text { Desulfovibrio sp. } \\
\text { Pseudomonas sp. }\end{array}$ & $\begin{array}{l}\text { Aerobic and } \\
\text { anaerobic }\end{array}$ & $\begin{array}{l}\text { Production of extracellular } \\
\text { polymeric substances (biofilm) }\end{array}$ & $\begin{array}{l}\text { Exopolymers capable of binding } \\
\text { metal ions }\end{array}$ & $\begin{array}{l}\text { San et al., 2011; Stadler et al., } \\
\text { 2008; Stadler et al., } 2010\end{array}$ \\
\hline
\end{tabular}




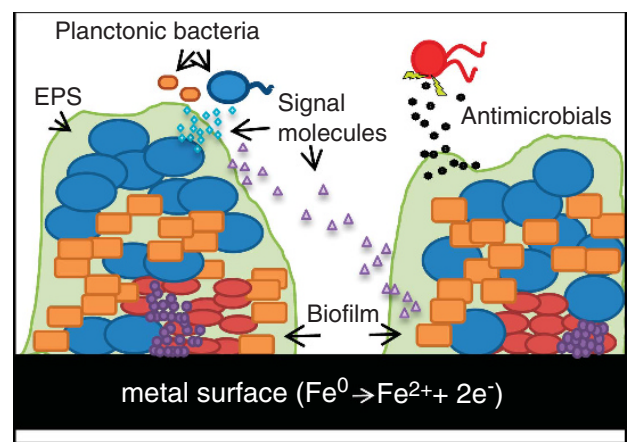

C

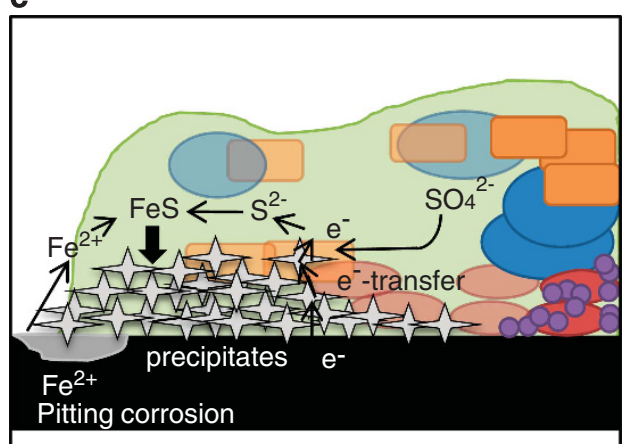

b

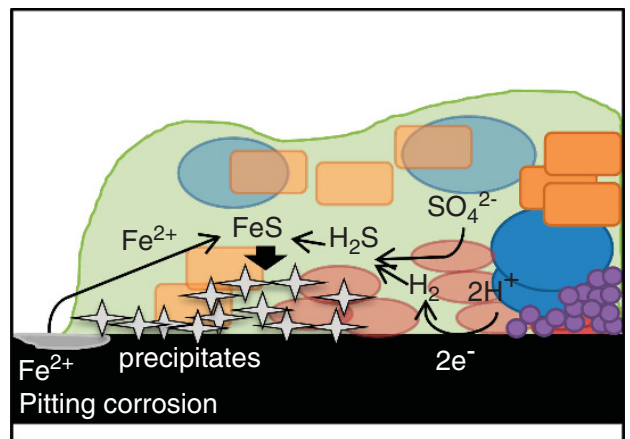

d

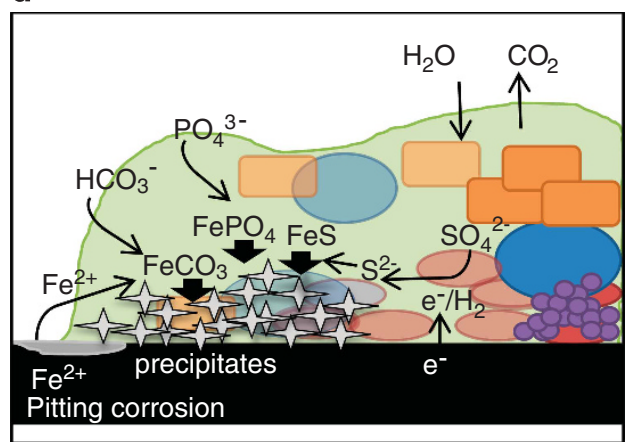

Figure 1 Schematic overview of a multispecies biofilm on a metal surface showing the possible reactions between the biofilm, the metal surface and the anaerobic environment. (a) A biofilm on a metal surface producing signal molecules and antimicrobials. (b) CMIC, chemical microbially induced corrosion by marine sulfate reducers. (c) EMIC, electrical microbially induced corrosion by marine sulfate reducers. (d) A multispecies biofilm showing the precipitation of several different precipitates.

\section{Conventional corrosion inhibition and prevention methods}

Current (bio) corrosion prevention methods, such as cleaning, coatings and electrochemical interference, are based on the inhibition of microbial growth and metabolism. Owing to the resistant nature of biofilms the treatment of established biofilms is often not effective for corrosion control (Simões et al., 2010). Regular cleaning and disinfection is used to reduce microbial attachment, but this is not always an option, for example, on pipelines buried in soil or in oceans (Parkar et al., 2004; Simões et al., 2010).

Another biocorrosion prevention method is to inhibit certain electrochemical reactions (Zuo, 2007; Neoh and Kang, 2011). This can be achieved by the application of protective coatings or either anodic or cathodic protection. However, many coatings have been shown to be subject to microbial degradation (Kopteva et al., 2004). Coatings with added antimicrobials were shown to inhibit microbial degradation (Gottenbos et al., 2002; Park et al., 2004), for example, silver-based coatings were effective in the inhibition of biofilm formation (Liedberg and Lundeberg, 1989). Unfortunately, the fact that antimicrobials can dissolve from the coating into the environment raises serious concerns. The cathodic protection method uses a sacrificial anode, which is an easily corroded metal that is attached to the protected metal. However, this method is expensive and only works in certain environments.

To protect stone and concrete, coatings are also applied, for example, consolidants, like epoxy resins, which bind the stone particles together (Karatasios et al., 2009). These resins polymerize inside the pores of the stone. However, this treatment clogs the pores and is subject to deterioration and in time can peel off, which aggravates the situation rather than improving it (Le MétayerLevrel et al., 1999).

\section{Metal corrosion inhibition using microbially based techniques}

The use of microbes to protect metals against corrosion has been shown to have great potential (Potekhina et al., 1999; Videla and Herrera, 2005). Zuo (2007) described three possible mechanisms of the inhibition of biofilm-induced metal corrosion: (1) removal of corrosive substances through microbial activity; for example, microbes consuming reactive oxygen through aerobic respiration, (2) growth inhibition of corrosion-causing microbes, for example, from antimicrobial production by non-corrosive microorganisms and (3) the formation of a protective layer, which could be established by overproduction of EPS by non-damaging microbes (Zuo, 2007; Videla and Herrera, 2009). 
In multispecies biofilms a combination of the different mechanisms may occur. In 1991, Pedersen and Hermansson already showed the inhibition of steel corrosion by two marine isolates, Pseudomonas sp.S9 and Serratia marcescens EF190. Corrosion inhibition was also detected when the metal and cell suspensions were separated, which led to the conclusion that corrosion protection was the result of metabolic activity, including oxygen consumption. Since then MICI has been studied by testing different materials and different bacterial species in different environments (see Table 3). The corrosioninhibition effect was tested by using aerobic biofilms grown on different types of metals. The single-species biofilms tested included Bacillus spp, Pseudomonas spp., Shewanella spp. and Spirulina platensis (nowadays Arthrospira) (Jayaraman et al., 1999a, b; Nagiub and Mansfeld, 2002; Chongdar et al., 2005; Mert et al., 2011). Both aerobic P. fragi biofilms and anaerobically grown Escherichia coli biofilms were shown to inhibit corrosion, but the aerobic biofilms decreased corrosion to a greater extent, which indicates that oxygen removal has a significant role in MICI (Jayaraman et al., 1997a, c). When Shewanella oneidensis mutants in which biofilm formation and/or iron respiration had been knocked down were grown on metal, an increase in corrosion rates was found when compared with the wild type, which indicates that the microbial respiration of the wild type and biofilm formation inhibit the corrosion processes (Dubiel et al., 2002).

The second MICI mechanism is the growth inhibition of corrosion-causing microorganisms. This has been investigated using biofilms that naturally produce antimicrobials, or using genetically engineered organisms, which produce antimicrobials that inhibit the growth of SRB (Jayaraman et al., 1997a, b, c; Jayaraman et al., 1999b; Zuo and Wood, 2004). The best results were obtained when antimicrobial-producing biofilms were applied, instead of only adding the antimicrobials. Bacillus brevis naturally produces gramicidin S, which inhibits corrosion by SRB on mild steel and stainless steel (Jayaraman et al., 1999a). Genetically

Table 3 Overview of MICI studies using different types of organism and materials

\begin{tabular}{|c|c|c|c|c|}
\hline Organism type & Organism(s) & Material(s) & Mode of action & Reference(s) \\
\hline \multirow[t]{17}{*}{ Bacteria } & $\begin{array}{l}\text { Pseudomonas spp. and Escheri- } \\
\text { chia coli }\end{array}$ & Carbon steel (SAE 1018) & $\begin{array}{l}\text { Protective biofilm, (oxygen } \\
\text { removal?) }\end{array}$ & Jayaraman et al., 1997a, b, c \\
\hline & $\begin{array}{l}\text { Pseudomonas Sp9 and Serratia } \\
\text { marcescens EF190 }\end{array}$ & Steel & $\begin{array}{l}\text { Metabolic activity (oxygen } \\
\text { removal?) }\end{array}$ & Pedersen and Hermansson, 1991 \\
\hline & Bacillus Brevis & Carbon steel (SAE 1018) & $\begin{array}{l}\text { SRB inhibition by produc- } \\
\text { tion of antimicrobials }\end{array}$ & Jayaraman et al., 1999a \\
\hline & $\begin{array}{l}\text { Pseudomonas fragi } K \text { and Bacillus } \\
\text { brevis } 18\end{array}$ & $\begin{array}{l}\text { Unalloyed copper and } \\
\text { aluminum alloy } 2024\end{array}$ & $\begin{array}{l}\text { Protective biofilm (oxygen } \\
\text { removal?) }\end{array}$ & Jayaraman et al., 1999c \\
\hline & Pseudomonas cichorii & Mild steel & $\begin{array}{l}\text { Protective biofilm, phos- } \\
\text { phate precipitation layer }\end{array}$ & Chongdar et al., 2005 \\
\hline & Shewanella algae and $S$. ana & $\begin{array}{l}\text { Aluminum, mild steel \& } \\
\text { brass }\end{array}$ & Protective biofilm & Nagiub and Mansfeld, 2002 \\
\hline & Shewanella oneidensis strain MR-1 & Mild steel 1018 & $\begin{array}{l}\text { Protective precipitation } \\
\text { layer }\end{array}$ & Dubiel et al., 2002 \\
\hline & Pseudomonas flava & Mild steel & $\begin{array}{l}\text { Protective biofilm, phos- } \\
\text { phate precipitation layer }\end{array}$ & Gunasekaran et al., 2004 \\
\hline & $\begin{array}{l}\text { Bacillus licheniformis and } \\
\text { B. subtilis }\end{array}$ & $\begin{array}{l}\text { Aluminum 2024-T3 and } \\
\text { C26000 brass }\end{array}$ & $\begin{array}{l}\text { Production of anionic corro- } \\
\text { sion inhibitors }\end{array}$ & $\begin{array}{l}\text { Mansfeld et al., 2002; Örnek et al., } \\
\text { 2002a, b }\end{array}$ \\
\hline & Spirulina platensis (Arthrospira): & Carbon steel & Protective biofilm & Mert et al., 2011 \\
\hline & Bacillus pasteurii & $\begin{array}{l}\text { Cement-based building } \\
\text { material }\end{array}$ & $\begin{array}{l}\text { Calcium carbonate } \\
\text { precipitation }\end{array}$ & Chunxiang et al., 2009 \\
\hline & $\begin{array}{l}\text { Myxococcus xanthus and other } \\
\text { carbonatogenic bacteria }\end{array}$ & $\begin{array}{l}\text { porous limestone } \\
\text { (calcarenite) }\end{array}$ & MICP & $\begin{array}{l}\text { Jroundi et al., 2010; Jroundi et al., } \\
\text { 2012; Piñar et al., } 2010\end{array}$ \\
\hline & Brevundimonas diminuta & $\begin{array}{l}\text { Calcitic and silicate } \\
\text { substrates }\end{array}$ & MICP & Rodriguez-Navarro et al., 2012 \\
\hline & Bacillus sphaericus & Concrete and mortar & MICP & De Muynck et al., 2008 \\
\hline & $\begin{array}{l}\text { Bacillus lentus and Bacillus } \\
\text { sphaericus }\end{array}$ & Limestone & MICP & Dick et al., 2006 \\
\hline & $\begin{array}{l}\text { Bacillus pseudofirmus DSM } 8715 \\
\text { and B. cohnii DSM } 6307\end{array}$ & Concrete & MICP & Jonkers et al., 2010 \\
\hline & not determined & Limestone & MICP & Zamarreño et al., 2009 \\
\hline \multirow[t]{2}{*}{ Unidentified bacteria } & Not determined & $\begin{array}{l}\text { Aluminum 2024, mild } \\
\text { steel and brass }\end{array}$ & Protective biofilm & Nagiub and Mansfeld, 2001b; 2002 \\
\hline & $\begin{array}{l}\text { Bacillus subtilis BE1500 and } \\
\text { B. subtilis WB600 }\end{array}$ & Carbon steel (SAE 1018) & $\begin{array}{l}\text { SRB inhibition by produc- } \\
\text { tion of antimicrobials }\end{array}$ & Jayaraman et al., 1999b \\
\hline \multirow[t]{2}{*}{$\begin{array}{l}\text { Genetically engineered } \\
\text { microorganisms }\end{array}$} & $\begin{array}{l}\text { Bacillus subtilis, Bacillus licheni- } \\
\text { formis and E. coli }\end{array}$ & $\begin{array}{l}\text { Aluminum } 2024 \text { and } \\
\text { C26000 brass }\end{array}$ & $\begin{array}{l}\text { Secretion of anionic corro- } \\
\text { sion inhibitors }\end{array}$ & $\begin{array}{l}\text { Mansfeld et al., 2002; Örnek et al., } \\
\text { 2002a, b }\end{array}$ \\
\hline & Beauveria bassiana & Ancient copper coins & $\begin{array}{l}\text { Protective copper oxalate } \\
\text { layer }\end{array}$ & Joseph et al., 2012 \\
\hline Fungi & $\begin{array}{l}\text { Aspergillus niger, Aspergillus } \\
\text { alliaceae, } \\
\text { Penicillium sp., Beauveria bassi- } \\
\text { ana and } \\
\text { Fusarium sp. }\end{array}$ & Bronze and copper & Protective oxalate layer & Joseph et al., 2011 \\
\hline
\end{tabular}

Abbreviations: MICP, microbial-induced carbonate precipitation; SRB, sulfate-reducing bacteria 
engineered B. subtillus biofilms secreting the antimicrobials indolicidin and bactenecin also reduced SRB-induced corrosion significantly (Jayaraman et al., 1999b). An additional advantage of the antimicrobial-producing biofilm is that relatively high local antimicrobial concentrations in the biofilm can be maintained without excessive diffusion into bulk fluids. Although there are different microbes involved in MIC, growth-inhibition studies have only been targeting the growth inhibition of SRB.

Other compounds have been shown to protect metals against corrosion, such as the negatively charged corrosion inhibitors, polyaspartate and $\gamma$-polyglutamate, secreted by bacterial biofilms (Mansfeld et al., 2002; Örnek et al., 2002a). As with coatings, the possible dissolution of antimicrobials into the environment remains a point of discussion.

Another corrosion control approach is biocompetitive exclusion (BE) (Videla and Herrera, 2005), which is applied in oil industries to exclude SRB from the local microbial community by promoting the growth of competing bacteria such as nitratereducing bacteria (Gieg et al., 2011).

Finally, recent studies showed that using the EPS, separated from the microbes, could reduce corrosion by SRB (Stadler et al., 2008, 2010; Finkenstadt et al., 2011). This corrosion protection by EPS appeared to be species dependent. The EPS of Desulfovibrio alaskensis inhibited corrosion, whereas the EPS of $D$ vulgaris and $D$ indonesiensis induced corrosion.

In all cases the mechanisms of the corrosion inhibition are not fully understood and different studies sometimes result in opposite conclusions, for example, in the case of iron-reducing bacteria that can cause or inhibit corrosion (Lee and Newman, 2003; Herrera and Videla, 2009). The above-mentioned studies are performed under controlled laboratory conditions with mostly single-species biofilms, which makes it difficult to extrapolate the results to realistic field conditions. In order to develop an application, there is a strong need for multispecies analyses under in situ conditions and samples from the field.

\section{Stone corrosion inhibition using microbially based techniques}

Corrosion of stone and concrete is fundamentally different from metal corrosion, and so corrosion protection needs a different approach. Alternative approaches, including the use of microbes in stone and concrete protection, have been under research for several decades and are already being used in recent years on historical buildings (Le MétayerLevrel et al., 1999; De Muynck et al., 2010).This environmentally friendly approach to stone and concrete protection is called microbial-induced carbonate precipitation (MICP; De Muynck et al., 2010; Phillips et al., 2013). This includes the precipitation of carbonate by so-called carbonatogenic bacteria (Le Métayer-Levrel et al., 1999) as well as algae and diatoms (Zavarzin, 2002). The microbially produced carbonate precipitates resemble the concrete and mortar material, attach to it and so reinforce the material and they can even small cracks are filled and repaired (Jonkers et al., 2010). Therefore, this is sometimes called self-healing concrete. The precipitation is called biologically induced or biologically controlled, depending on the influence of microbes and the environment. Biologically controlled precipitation is independent of environmental conditions and specific types of minerals are formed depending on the microorganisms (De Muynck et al., 2008). In the case of biologically induced precipitation, the environmental conditions have a large influence, for example, in the case of calcium carbonate production by bacteria, which is determined by calcium concentration, dissolved inorganic carbon concentration, $\mathrm{pH}$ and the availability of nucleation sites (De Muynck et al., 2010; Rodriguez-Navarro et al., 2012). Calcium carbonate precipitation by Sporosarcina pasteurii decreased water uptake, permeability and chloride penetration, enhancing the durability of concrete structures (Bang et al., 2010; Achal et al., 2011). In view of the conservation of archeological and historical sites and structures, carbonatogenic bacteria have successfully been used to protect limestone and concrete against corrosion as well (Le Métayer-Levrel et al., 1999; Ettenauer et al., 2011). Different types of bacteria have been tested for the consolidation of stone statues and buildings, including Bacillus spp. and Myхососcus sp. (Table 3; Rodriguez-Navarro et al., 2003; Jimenez-Lopez et al., 2008; Ettenauer et al., 2011). Myхососcus xanthus is able to induce the precipitation of a range of carbonates, phosphates and sulfates, which is important because the biomineralized cement must be compatible with the substrate. Another advantage is the motility of $M$. xanthus, which increases the potential protected surface because they are able to migrate inside the porous material, thereby increasing the consolidation efficiency (Jimenez-Lopez et al., 2008). Addition of $M$. xanthus to stone also was shown to induce the growth of other carbonatogenic microorganisms present in and on the stone, such as Pseudomonas sp., Bacillus sp. and Brevibacillus sp. (Piñar et al., 2010).

Two types of stone consolidation treatments based on biomineralization are used: (1) the inoculation of a carbonatogenic bacterial culture and (2) the application of culture media that will activate the in situ carbonatogenic bacterial community (Jroundi et al., 2012). As the mineral precipitates should be compatible with the material, the use of the in situ bacterial community enlarges the chances of successful bioconsolidation (Zamarreño et al., 2009; Jroundi et al., 2012). 


\section{Perspectives}

Microbial investigations on MIC and MICI, especially on metal, have been focused on laboratory experiments with single-species biofilms, even though the synergistic effect of multispecies biofilms is already known. Also, there is an increase in contradictory reports on both accelerating and inhibiting actions on the corrosion process of the same functional group of microorganisms, such as sulfate reducers (Enning et al., 2012; Venzlaff et al., 2013), iron reducers (AlAbbas et al., 2013) and methanogens (Uchiyama et al., 2010). These studies show a strong species specificity for either MIC or MICI, which indicates that there is an urgent need to focus on the mechanisms rather than on the presence of certain functional groups, which is common practice at the moment. The use of molecular techniques for community analysis is still rare in corrosion studies. Denaturing gradient gel electrophoresis (DGGE) on corroded iron and oil pipelines (Bermont-Bouis et al., 2007; Duncan et al., 2009; Oliveira et al., 2011; Cote et al., 2014; Marty et al., 2014) showed that the microbial communities involved in corrosion are much more complex than was found so far with culturing methods. Standard metal biocorrosion-monitoring procedures focus mainly on SRB detection, and although SRB are also found in many molecular studies they are not always the most abundant or most relevant microorganisms. Some of the above-mentioned studies do not make use of the full potential of the current molecular tools. Modern metagenomics approaches have only scarcely been applied in corrosion studies. Gomez-Alvarez et al. (2012) analyzed the microbial community in corroded wastewater pipes and they were able to relate the corrosion to sulfur and nitrogen pathways. Sampling is an important issue, because in oil industry most samples are water samples and they do not represent the microbial community attached to the pipeline walls (Skovhus et al., 2011).

Full understanding of the MICI and MIC processes requires the combination of expertise of scientists from different disciplines; as this is often not the case, great opportunities to improve the fundamental knowledge of the processes involved have been missed. For example, material scientists discovered that a bacterial contamination inhibited corrosion after insufficient sterilization of their electrodes (Nagiub and Mansfeld, 2001). However, this bacterial contamination was not further examined. Also, applying recent advances in molecular microbiological detection techniques to archeological excavation sites where natural protective layers are found may provide vital information on long-term processes, and, together with geochemical and mineralogical data, it might be a step closer to understanding the different mechanisms.

Recent discoveries have shown the importance of the ability to use $\mathrm{Fe}^{0}$ as an electron donor, rather than hydrogen, as was shown in the CMIC vs EMIC mechanisms in marine SRB. Electrochemically active biofilms have been investigated in microbial fuel cell research and researchers have tried to understand the mechanisms of electron transfer between microorganisms and metals (Babauta et al., 2012). Several molecular studies revealed the role of pili and of multiheme outer-membrane c-type cytochromes in electron transfer (Butler et al., 2010, Lovley, 2012). A comparative metatranscriptomic analysis revealed eight genes with no annotated protein function to be related to electrochemical activity (Ishii et al., 2013). Both the fields of corrosion and microbial fuel cell research can benefit from these in-depth studies.

When analyzing the existing literature, several approaches emerge as potentially successful MICI mechanisms. The first is a protective biofilm that works primarily as a coating and delivers protection when the metabolic activity reduces corrosioncausing reactions or growth of corrosion-causing organisms. There are only few examples of lab experiments in which single-organism biofilms were tested.

The second MICI mechanism is microbially induced precipitation of compounds to protect the material against corrosion. In stone protection, microbially induced precipitation is already applied in certain industries. However, for metal corrosion microbially induced protection requires better understanding of the processes involved before it can be applied in full practice. One application is known to be successful: Beauveria bassiana produces copper-oxalate complexes, thereby forming a protective coating on copper objects (Joseph et al., 2012). There are few examples, such as the biofilms of Pseudomonas spp. grown on steel electrodes, that showed the production of a protective layer of iron oxides and iron phosphates (Chongdar et al., 2005). Also, Pseudomonas and Rhodococcus sp. biofilms were shown to produce corrosion-inhibiting layers of phosphate minerals on metal surfaces (Volkland et al., 2000, 2001). The EPS layer of biofilms has an important role in the mineral precipitation process, for example, the organo-metal (iron-EPS) complex in which the EPS interacts with the dissolved metal to form a complex (Chongdar et al., 2005; Decho, 2010). For EPS also species specificity has a role, for example, EPS of $P$. cichorii comprising neutral carbonyl groups forms a protective complex, but the EPS of $P$. alcaligenes was acidic and even aggravated the corrosion of mild steel (Chongdar et al., 2005).

Corrosion-inhibiting mineral layers deposited by microbes on iron have great biotechnological potential. This natural coating may even thrive in the natural environment because in marine and soil environments the precipitation of phosphate and that of carbonate are common processes (Castanier et al., 1999; Krumbein, 1974). There are some examples of naturally formed mineral precipitation 
layers, for example, on metallic radioactive waste containers stored in deep geological environments, in which a protective magnetite layer $\left(\mathrm{Fe}_{3} \mathrm{O}_{4}\right)$ was observed (Esnault et al., 2011). Other examples are found in archeological excavation sites, where iron objects thousand years old can still be found relatively unaffected by corrosion (Booth et al., 1962a, b). These objects contained a protective layer of mixed ferrous and ferric phosphates, even in highly aggressive soils. It is still not understood how these protective layers are formed and what the influence of microbes is on these systems. The input of microbial and molecular analysis of these unique field samples might enable a better understanding of the processes that take place at the metal surface in natural environments. New corrosion-mitigation strategies can be developed, for example, using microbial communities that are naturally present in the soil to produce a protective mineral layer on metal, similar to the approach in stone consolidation processes.

Finally, corrosion science lags behind in using the molecular toolkit to its full extent, but based on recent developments with respect to species specificities and EMIC vs CMIC, these approaches may be prerequisite sine qua non to get to a better understanding of MIC and MICI. Also interdisciplinary collaborations are needed to obtain a better understanding of electrochemically active biofilms.

\section{Conflict of Interest}

The authors declare no conflict of interest.

\section{Acknowledgements}

We would like to thank Noriko Cassman for critical reading of the manuscript. This research is supported by the Dutch Technology Foundation STW, which is part of the Netherlands Organisation for Scientific Research (NWO), and which is partly funded by the Ministry of Economic Affairs grant number 11333. The BioCoPro project under the leadership of Timo Heimovaara is an STW-sponsored Perspective Programme Bio-Based Geo \& Civil engineering for a Sustainable Society (BioGeoCivil) program. Publication number 5652 of the NIOO-KNAW, Netherlands Institute of Ecology.

\section{References}

Achal V, Mukherjee A, Reddy M. (2011). Effect of calcifying bacteria on permeation properties of concrete structures. J Ind Microbiol Biotechnol 38: 1229-1234.

AlAbbas FM, Bhola SM, Spear JR, Olson DL, Mishra B. (2013). The shielding effect of wild type iron reducing bacterial flora on the corrosion of linepipe steel. Eng Fail Anal 33: 222-235.

Babauta J, Renslow R, Lewandowski Z, Beyenal H. (2012). Electrochemically active biofilms: facts and fiction. A review. Biofouling 28: 789-812.
Bang SS, Lippert JJ, Yerra U, Mulukutla S, Ramakrishnan V. (2010). Microbial calcite, a bio-based smart nanomaterial in concrete remediation. Int J Smart Nano Mater 1: 28-39.

Beech IB, Gaylarde CC. (1999). Recent advances in the study of biocorrosion: an overview. Revista de Microbiologia 30: 117-190.

Bermont-Bouis D, Janvier M, Grimont PAD, Dupont I, Vallaeys T. (2007). Both sulfate-reducing bacteria and enterobacteriaceae take part in marine biocorrosion of carbon steel. J Appl Microbiol 102: 161-168.

Booth GH, Tiller AK, Wormwell F. (1962a). A laboratory study of well-preserved ancient iron nails from apparently corrosive soils. Corros Sci 2: 197-202.

Booth GH, Tiller AK, Wormwell F. (1962b). Ancient iron nails well preserved from apparently corrosive soils. Nature 195: 376-377.

Butler J, Young N, Lovley D. (2010). Evolution of electron transfer out of the cell: comparative genomics of six geobacter genomes. BMC Genomics 11: 1-12.

Castanier S, Le Métayer-Levrel G, Perthuisot J-P. (1999). Ca-carbonates precipitation and limestone genesisthe microbiogeologist point of view. Sediment Geol 126: 9-23.

Chongdar S, Gunasekaran G, Kumar P. (2005). Corrosion inhibition of mild steel by aerobic biofilm. Electrochim Acta 50: 4655-4665.

Chunxiang Q, Jianyun W, Ruixing W, Liang C. (2009). Corrosion protection of cement-based building materials by surface deposition of $\mathrm{CaCO} 3$ by Bacillus pasteurii. Mater Sci Eng C 29: 1273-1280.

Cote C, Rosas O, Sztyler M, Doma J, Beech I, Basseguy R. (2014). Corrosion of low carbon steel by microorganisms from the 'pigging' operation debris in water injection pipelines. Bioelectrochemistry 97: 97-109.

Crispim CA, Gaylarde CC. (2005). Cyanobacteria and biodeterioration of cultural heritage: a review. Microbial Ecol 49: 1-9.

De Muynck W, Debrouwer D, De Belie N, Verstraete W. (2008). Bacterial carbonate precipitation improves the durability of cementitious materials. Cem Concr Res 38: 1005-1014.

De Muynck W, De Belie N, Verstraete W. (2010). Microbial carbonate precipitation in construction materials: a review. Ecol Eng 36: 118-136.

Decho AW. (2010). Overview of biopolymer-induced mineralization: what goes on in biofilms? Ecol Eng 36: 137-144.

Dick J, Windt W, Graef B, Saveyn H, Meeren P, Belie N et al. (2006). Bio-deposition of a calcium carbonate layer on degraded limestone by Bacillus species. Biodegradation 17: 357-367.

Dubiel M, Hsu CH, Chien CC, Mansfeld F, Newman DK. (2002). Microbial iron respiration can protect steel from corrosion. Appl Environ Microbiol 68: 1440-1445.

Duncan KE, Gieg LM, Parisi VA, Tanner RS, Tringe SG, Bristow J et al. (2009). Biocorrosive thermophilic microbial communities in alaskan north slope oil facilities. Environ Sci Technol 43: 7977-7984.

Emerson D, Fleming EJ, McBeth JM. (2010). Iron-oxidizing bacteria: an environmental and genomic perspective. Annu Rev Microbiol 64: 561-583.

Enning D, Venzlaff H, Garrelfs J, Dinh HT, Meyer V, Mayrhofer K et al. (2012). Marine sulfate-reducing bacteria cause serious corrosion of iron under electroconductive biogenic mineral crust. Environ Microbiol 14: 1772-1787. 
Enning D, Garrelfs J. (2014). Corrosion of iron by sulfatereducing bacteria-new views of an old problem. Appl Environ Microbiol 80: 1226-1236.

Esnault L, Jullien M, Mustin C, Bildstein O, Libert M. (2011). Metallic corrosion processes reactivation sustained by iron-reducing bacteria: implication on long-term stability of protective layers. Phys Chem Earth 36: 1624-1629.

Ettenauer J, Piñar G, Sterflinger K, Gonzalez-Muñoz MT, Jroundi F. (2011). Molecular monitoring of the microbial dynamics occurring on historical limestone buildings during and after the in situ application of different bio-consolidation treatments. Sci Total Environ 409: 5337-5352.

Finkenstadt V, Côté G, Willett J. (2011). Corrosion protection of low-carbon steel using exopolysaccharide coatings from Leuconostoc mesenteroides. Biotechnol Lett 33: 1093-1100.

Gaylarde CC, Morton LHG, Loh K, Shirakawa MA. (2011). Biodeterioration of external architectural paint films-a review. Int Biodeter Biodegrad 65: 1189-1198.

Gieg L, Jack T, Foght J. (2011). Biological souring and mitigation in oil reservoirs. Appl Microbiol Biotechnol 92: 263-282.

Gomez-Alvarez V, Revetta R, Domingo JW. (2012). Metagenome analyses of corroded concrete wastewater pipe biofilms reveal a complex microbial system. BMC Microbiol 12: 122.

Gottenbos B, van der Mei HC, Klatter F, Nieuwenhuis P, Busscher HJ. (2002). In vitro and in vivo antimicrobial activity of covalently coupled quaternary ammonium silane coatings on silicone rubber. Biomaterials 23: 1417-1423.

Gunasekaran G, Chongdar S, Gaonkar SN, Kumar P. (2004). Influence of bacteria on film formation inhibiting corrosion. Corros Sci 46: 1953-1967.

Hamilton WA. (2003). Microbially influenced corrosion as a model system for the study of metal microbe interactions: a unifying electron transfer hypothesis. Biofouling 19: 65-76.

Herrera LK, Videla HA. (2009). Role of iron-reducing bacteria in corrosion and protection of carbon steel. Int Biodeter Biodegrad 63: 891-895.

Ishii S, Suzuki S, Norden-Krichmar TM, Tenney A, Chain PSG, Scholz MB et al. (2013). A novel metatranscriptomic approach to identify gene expression dynamics during extracellular electron transfer. Nat Commun 4: 1601.

Jayaraman A, Cheng ET, Earthman JC, Wood TK. (1997a). Axenic aerobic biofilms inhibit corrosion of SAE 1018 steel through oxygen depletion. Appl Microbiol Biotechnol 48: 11-17.

Jayaraman A, Cheng ET, Earthman JC, Wood TK. (1997b). Importance of biofilm formation for corrosion inhibition of SAE 1018 steel by axenic aerobic biofilms. J Ind Microbiol Biotechnol 18: 396-401.

Jayaraman A, Earthman JC, Wood TK. (1997c). Corrosion inhibition by aerobic biofilms on SAE 1018 steel. Appl Microbiol Biotechnol 47: 62-68.

Jayaraman A, Hallock PJ, Carson RM, Lee CC, Mansfeld FB, Wood TK. (1999a). Inhibiting sulfatereducing bacteria in biofilms on steel with antimicrobial peptides generated in situ. Appl Microbiol Biotechnol 52: 267-275.

Jayaraman A, Mansfeld FB, Wood TK. (1999b). Inhibiting sulfate-reducing bacteria in biofilms by expressing the antimicrobial peptides indolicidin and bactenecin. $J$ Ind Microbiol Biotechnol 22: 167-175.

Jayaraman A, Ornek D, Duarte DA, Lee CC, Mansfeld FB, Wood TK. (1999c). Axenic aerobic biofilms inhibit corrosion of copper and aluminum. Appl Microbiol Biotechnol 52: 787-790.

Jimenez-Lopez C, Jroundi F, Pascolini C, Rodriguez-Navarro C, Piñar-Larrubia G, Rodriguez-Gallego M et al. (2008). Consolidation of quarry calcarenite by calcium carbonate precipitation induced by bacteria activated among the microbiota inhabiting the stone. Int Biodeter Biodegrad 62: 352-363.

Jonkers HM, Thijssen A, Muyzer G, Copuroglu O, Schlangen E. (2010). Application of bacteria as self-healing agent for the development of sustainable concrete. Ecol Eng 36: 230-235.

Joseph E, Simon A, Prati S, Wörle M, Job D, Mazzeo R. (2011). Development of an analytical procedure for evaluation of the protective behaviour of innovative fungal patinas on archaeological and artistic metal artefacts. Anal Bioanal Chem 399: 2899-2907.

Joseph E, Cario S, Simon A, Wörle M, Mazzeo R, Junier P et al. (2012). Protection of metal artefacts with the formation of metal-oxalates complexes by Beauveria bassiana. Front Microbiol 2: 270.

Jroundi F, Fernández-Vivas A, Rodriguez-Navarro C, Bedmar E, González-Muñoz M. (2010). Bioconservation of deteriorated monumental calcarenite stone and identification of bacteria with carbonatogenic activity. Microb Ecol 60: 39-54.

Jroundi F, Gómez-Suaga P, Jimenez-Lopez C, González-Muñoz MT, Fernandez-Vivas MA. (2012). Stone-isolated carbonatogenic bacteria as inoculants in bioconsolidation treatments for historical limestone. Sci Total Environ 425: 89-98.

Juzeliūnas E, Ramanauskas R, Lugauskas A, Leinartas K, Samulevičienè M, Sudavičius A et al. (2007). Microbially influenced corrosion of zinc and aluminium-two-year subjection to influence of Aspergillus niger. Corros Sci 49: 4098-4112.

Karatasios I, Theoulakis P, Kalagri A, Sapalidis A, Kilikoglou V. (2009). Evaluation of consolidation treatments of marly limestones used in archaeological monuments. Constr Build Mater 23: 2803-2812.

Kopteva ZP, Zanina VV, Kozlova IA. (2004). Microbial corrosion of protective coatings. Surf Eng 20: 275-280.

Krumbein WE. (1974). On the precipitation of aragonite on the surface of marine bacteria. Naturwissenschaften 61: 167-167.

Lamenti G, Tiano P, Tomaselli L. (2000). Biodeterioration of ornamental marble statues in the Boboli gardens (Florence, Italy). J Appl Phycol 12: 427-433.

Le Métayer-Levrel G, Castanier S, Orial G, Loubière JF, Perthuisot JP. (1999). Applications of bacterial carbonatogenesis to the protection and regeneration of limestones in buildings and historic patrimony. Sediment Geol 126: 25-34.

Lee AK, Newman DK. (2003). Microbial iron respiration: impacts on corrosion processes. Appl Microbiol Biotechnol 62: 134-139.

Lee JS, McBeth JM, Ray RI, Little BJ, Emerson D. (2013). Iron cycling at corroding carbon steel surfaces. Biofouling 29: 1243-1252.

Li S, Zhang Y, Liu J, Yu M. (2008). Corrosion behavior of steel A3 influenced by Thiobacillus ferrooxidans. Acta Phys-Chim Sin 24: 1553-1557. 
Liedberg H, Lundeberg T. (1989). Silver coating of urinary cathethers prevents adherence and growth of Pseudomonas aeruginosa. Urol Res 17: 357-358.

Linhardt P. (2010). Twenty years of experience with corrosion failures caused by manganese oxidizing microorganisms. Mater Corros 61: 1034-1039.

Little B, Staehle R, Davis R. (2001). Fungal influenced corrosion of post-tensioned cables. Int Biodeterior Biodegrad 47: 71-77.

Lovley DR. (2012). Electromicrobiology. Ann Rev Microbiol 66: 391-409.

Mansfeld F, Hsu H, Ornek D, Wood TK, Syrett BC. (2002). Corrosion control using regenerative biofilms on Aluminum 2024 and brass in different media. J Electrochem Soc 149: B130-B138.

Mapelli F, Marasco R, Balloi A, Rolli E, Cappitelli F, Daffonchio D et al. (2012). Mineral-microbe interactions: biotechnological potential of bioweathering. J Biotechnol 157: 473-481.

Marty F, Gueuné H, Malard E, Sánchez-Amaya JM, Sjögren L, Abbas B et al. (2014). Identification of key factors in accelerated low water corrosion through experimental simulation of tidal conditions: influence of stimulated indigenous microbiota. Biofouling 30: 281-297.

McBeth JM, Little BJ, Ray RI, Farrar KM, Emerson D. (2011). Neutrophilic iron-oxidizing 'zetaproteobacteria' and mild steel corrosion in nearshore marine environments. Appl Environ Microbiol 77: 1405-1412.

Mert BD, Mert ME, Kardaş G, Yazıcı B. (2011). The role of Spirulina platensis on corrosion behavior of carbon steel. Mater Chem Phys 130: 697-701.

Nagiub A, Mansfeld F. (2001). Microbiologically influenced corrosion inhibition (MICI) due to bacterial contamination. Mater Corros 52: 817-826.

Nagiub A, Mansfeld F. (2002). Evaluation of microbiologically influenced corrosion inhibition (MICI) with eis and ena. Electrochim Acta 47: 2319-2333.

Neoh KG, Kang ET. (2011). Combating bacterial colonization on metals via polymer coatings: relevance to marine and medical applications. ACS Appl Mater Interfaces 3: 2808-2819.

Oliveira VM, Lopes-Oliveira PF, Passarini MRZ, Menezes CBA, Oliveira WRC, Rocha AJ et al. (2011). Molecular analysis of microbial diversity in corrosion samples from energy transmission towers. Biofouling 27: 435-447.

Örnek D, Jayaraman A, Syrett BC, Hsu CH, Mansfeld FB, Wood TK. (2002a). Pitting corrosion inhibition of aluminum 2024 by Bacillus biofilms secreting polyaspartate or $\gamma$-polyglutamate. Appl Microbiol Biotechnol 58: 651-657.

Örnek D, Wood TK, Hsu CH, Mansfeld F. (2002b). Corrosion control using regenerative biofilms (CCURB) on brass in different media. Corros Sci 44: 2291-2302.

Park SI, Daeschel MA, Zhao Y. (2004). Functional properties of antimicrobial lysozyme-chitosan composite films. J Food Sci 69: M215-M221.

Parkar SG, Flint SH, Brooks JD. (2004). Evaluation of the effect of cleaning regimes on biofilms of thermophilic bacilli on stainless steel. J Appl Microbiol 96: 110-116.

Pedersen A, Hermansson M. (1991). Inhibition of metal corrosion by bacteria. Biofouling 3: 1-11.

Phillips AJ, Gerlach R, Lauchnor E, Mitchell AC, Cunningham AB, Spangler L. (2013). Engineered applications of ureolytic biomineralization: a review. Biofouling 29: 715-733.
Piñar G, Jimenez-Lopez C, Sterflinger K, Ettenauer J, Jroundi F, Fernandez-Vivas A et al. (2010). Bacterial community dynamics during the application of a Myxococcus xanthus inoculated culture medium used for consolidation of ornamental limestone. Microbial Ecol 60: 15-28.

Potekhina JS, Sherisheva NG, Povetkina LP, Pospelov AP, Rakitina TA, Warnecke $\mathrm{F}$ et al. (1999). Role of microorganisms in corrosion inhibition of metals in aquatic habitats. Appl Microbiol Biotechnol 52: 639-646.

Rao TS, Sairam TN, Viswanathan B, Nair KVK. (2000). Carbon steel corrosion by iron oxidising and sulphate reducing bacteria in a freshwater cooling system. Corros Sci 42: 1417-1431.

Rodriguez-Navarro C, Rodriguez-Gallego M, Ben Chekroun K, Gonzalez-Muñoz MT. (2003). Conservation of ornamental stone by Myxососcus xanthus-induced carbonate biomineralization. Appl Environ Microbiol 69: 2182-2193.

Rodriguez-Navarro C, Jroundi F, Schiro M, Ruiz-Agudo E, González-Muñoz MT. (2012). Influence of substrate mineralogy on bacterial mineralization of calcium carbonate: implications for stone conservation. Appl Environ Microbiol 78: 4017-4029.

San NO, Nazır H, Dönmez G. (2011). Microbial corrosion of Ni-Cu alloys by Aeromonas eucrenophila bacterium. Corros Sci 53: 2216-2221.

Sánchez del Junco A, Moreno DA, Ranninger C, Ortega-Calvo JJ, Sáiz-Jiménez C. (1992). Microbial induced corrosion of metallic antiquities and works of art: a critical review. Int Biodeter Biodegr 29: 367-375.

Simões M, Simões LC, Vieira MJ. (2010). A review of current and emergent biofilm control strategies. LWT-Food Sci Technol 43: 573-583.

Skovhus TL, Sørensen KB, Larsen J. (2011). Problems caused by microbes and treatment strategies: rapid diagnostics of microbiologically influenced corrosion (MIC) in oilfield systems with a DNA-based test kit. In: Whitby C, Skovhus TL (eds). Applied Microbiology and Molecular Biology in Oilfield Systems. Springer: Dordrecht, The Netherlands, pp 133-140.

Stadler R, Fuerbeth W, Harneit K, Grooters M, Woellbrink M, Sand W. (2008). First evaluation of the applicability of microbial extracellular polymeric substances for corrosion protection of metal substrates. Electrochim Acta 54: 91-99.

Stadler R, Wei L, Fürbeth W, Grooters M, Kuklinski A. (2010). Influence of bacterial exopolymers on cell adhesion of desulfovibrio vulgaris on high alloyed steel: corrosion inhibition by extracellular polymeric substances (EPS). Mater Corros 61: 1008-1016.

Uchiyama T, Ito K, Mori K, Tsurumaru H, Harayama S. (2010). Iron-corroding methanogen isolated from a crude-oil storage tank. Appl Environ Microbiol 76: 1783-1788.

Usher KM, Kaksonen AH, MacLeod ID. (2014). Marine rust tubercles harbour iron corroding archaea and sulphate reducing bacteria. Corros Sci 83: 189-197.

Venzlaff H, Enning D, Srinivasan J, Mayrhofer KJJ, Hassel AW, Widdel F et al. (2013). Accelerated cathodic reaction in microbial corrosion of iron due to direct electron uptake by sulfate-reducing bacteria. Corros Sci 66: 88-96. 
Videla HA, Herrera LK. (2005). Microbiologically influenced corrosion: looking to the future. Int Microbiol 8: 169-180.

Videla HA, Herrera LK. (2009). Understanding microbial inhibition of corrosion. a comprehensive overview. Int Biodeter Biodegrad 63: 896-900.

Volkland H-P, Harms H, Müller B, Repphun G, Wanner O, Zehnder AJB. (2000). Bacterial phosphating of mild (unalloyed) steel. Appl Environ Microbiol 66: 4389-4395.

Volkland H-P, Harms H, Kaufmann K, Wanner O, Zehnder AJB. (2001). Repair of damaged vivianite coatings on mild steel using bacteria. Corros Sci 43: 2135-2146.

Vollertsen J, Nielsen AH, Jensen HS, Wium-Andersen T, Hvitved-Jacobsen T. (2008). Corrosion of concrete sewers-the kinetics of hydrogen sulfide oxidation. Sci Total Environ 394: 162-170.
Warscheid T, Braams J. (2000). Biodeterioration of stone: a review. Int Biodeter Biodegrad 46: 343-368.

Wikieł AJ, Datsenko I, Vera M, Sand W. (2014). Impact of Desulfovibrio alaskensis biofilms on corrosion behaviour of carbon steel in marine environment. Bioelectrochemistry 97: 52-60.

Zamarreño DV, Inkpen R, May E. (2009). Carbonate crystals precipitated by freshwater bacteria and their use as a limestone consolidant. Appl Environ Microbiol 75: 5981-5990.

Zavarzin GA. (2002). Microbial geochemical calcium cycle. Microbiology 71: 1-17.

Zuo R, Wood TK. (2004). Inhibiting mild steel corrosion from sulfate-reducing and iron-oxidizing bacteria using gramicidin-S-producing biofilms. Appl Microbiol Biotechnol 65: 747-753.

Zuo R. (2007). Biofilms: strategies for metal corrosion inhibition employing microorganisms. Appl Microbiol Biotechnol 76: 1245-1253. 